\title{
Spawning habits and embryonic development of the lampeye killifish Aplocheilichthys spilauchen in ex situ fresh-and-brackish water environments
}

Isaac Okyere ( $\square$ iokyere@ucc.edu.gh )

Department of Fisheries and Aquatic Sciences, School of Biological Sciences, University of Cape Coast, Cape Coast, Ghana https://orcid.org/0000-0001-8725-1555

Juliet Afrah Obeng

Department of Fisheries and Aquatic Sciences, School of Biological Sciences, University of Cape Coast, Cape Coast, Ghana

\section{Samuel Ayitey}

Department of Fisheries and Aquatic Sciences, School of Biological Sciences, University of Cape Coast, Cape Coast, Ghana

Jouke Rients Van der Zee

Zoology Department, Ichthyology, Royal Museum for Central Africa, Tervuren, Belgium

Herman Meeus

Belgian Killifish Association (BKV), De Reet 6, B 2160 Wommelgem, Belgium

\section{Research Article}

Keywords: Killifish, Banded lampeye, Spawning habits, Substrate preference, Embryonic development

Posted Date: December 21st, 2020

DOl: https://doi.org/10.21203/rs.3.rs-132624/v1

License: (1) This work is licensed under a Creative Commons Attribution 4.0 International License. Read Full License

Version of Record: A version of this preprint was published at Journal of Fish Biology on December 21st, 2020. See the published version at https://doi.org/10.1111/jfb.14729. 


\section{Abstract}

Aside from ornamental uses of killifishes, there is growing interest in using killies for a multiplicity of purposes including baitfish and mosquito biocontrol. This experiment explored the spawning habits and embryonic development of the banded lampeye, Aplocheilichthys spilauchen in ex situ freshwater (0.04 $\%$ ) and brackish water (5.01\%o) to ascertaining the captive breeding prospects for mosquito control in areas where they occur. Significantly higher number of eggs were laid in the brackish water than the freshwater $\left(\square^{2}=1613.0, P<0.05\right)$, and black mop was the most preferred spawning substrate, followed by green, blue and white mops. Microscopic monitoring of embryos revealed that cleavage occurred within the first 30 minutes after fertilisation, organogenesis commenced in averagely the $25^{\text {th }}$ hour, and hatching in approximately 230 hours. Although certain embryonic developmental stages occurred faster in the freshwater than brackish water and freshwater eggs were relatively bigger than brackish water eggs, these differences were overall not significant and had no effects on the development and hatching. The observed outcome that $A$. spilauchen can be optimally propagated with black mops in brackish water offers a significant step in its use for the mosquito biocontrol programme, as well as other potential uses not yet explored.

\section{Introduction}

The need to explore biological control options in managing mosquitoes as disease vectors due to reported negative effects of chemical control approaches has been iteratively advocated (Dabire et al. 2008; Munhenga et al. 2008). Earlier global interest in exploring the prospects of using fish for mosquito biocontrol, and importantly the introduction of mosquitofish Gambusia spp. into many countries to curb mosquito populations which failed in the 1990s due to its intrinsic aggression on native fish species (Leyse et al., 2004), has reshaped the choices of fish species for mosquito control programmes (see Matias \& Adrias, 2010; Okyere et al., 2019). Recent efforts have refocused on exploring indigenous killifishes (a group of small, non-aggressive cyprinodontiform fishes) due to a number of desirable traits exhibited by these fishes especially their larvivorous predatory habits and non-aggressive nature which make them suitable biocontrol candidates (Ghosh et al., 2004; Matias \& Adrias, 2010). The goal is to use native killifishes for mosquito control in localities where they occur naturally rather than introducing nonnative species.

One of such killifish species with wider geographical distribution along the West Coast of Africa (Wildekamp, 1995) that is being explored in Ghana for its mosquito biocontrol prospects is the banded lampeye, Aplocheilichthys spilauchen (Duméril 1861), the first described killifish from Africa (Wildekamp et al., 1986). A previous study by Okyere (2012) on the food habits of A. spilauchen population from coastal wetland pools in Ghana indicated that the fish could be a potential candidate for mosquito control due to its predatory habits on insects such as chironomid (midge) larvae. A follow up laboratory experimental study on the food selectivity and prey preference of the fish by Okyere et al. (2019) further 
confirmed the killifish as a promising biocontrol tool, as it selected mosquito larvae and chironomid larvae in equal proportions depending on abundance.

Aside feeding habits, another critical determinant of the feasibility and success of utilizing the killifish for mosquito control is its reproductive habits especially the ability to spawn in captivity. Given that the species inhabits both freshwater and brackish water environments including coastal swamps, river mouths, lagoons and mangrove swamps (Wildekamp, 1995; Lanés et al., 2012), an understanding of its reproductive habits in fresh-and-brackish water environments is imperatively required to inform targeted breeding and up scaling for the biocontrol programme.

To this end, the current work explored the spawning habits and embryonic development of $A$. spilauchen in captivity under freshwater and brackish water conditions as a continuity research in ascertaining the prospects of breeding and using the species for mosquito control in areas where they occur. Premised on previous findings that the species is a continuous substrate spawner with low fecundity (Okyere, 2012), this experiment (1) assessed the spawning potential, (2) investigated whether the killifish has preference for the colour of its spawning substrate, (3) monitored the stages of embryonic development, and (4) monitored the sizes of embryos and duration of embryonic development, in ex situ fresh-and-brackish water environments. With the growing interests in using killifish for a multiplicity of purposes including breeding for baitfish (Chesser et al., 2019) and as tool for embryology education (Genade, 2016), the usefulness this study may possibly traverse biocontrol to other facets killifish utility.

\section{Materials And Methods}

The experiment was commenced in September 2018 and ended in April 2019. Specimens of $A$. spilauchen used were collected from the mouth of the Kakum River near Cape Coast in the Central Region of Ghana ( $5^{\circ} 6^{\prime} \mathrm{N} ; 1^{\circ} 18^{\prime} \mathrm{W}$; see Okyere, 2012) and transported into six round plastic experimental tanks at the Department of Fisheries and Aquatic Sciences, University of Cape Coast. Three of the tanks contained replicate brackish water of salinity $5.01 \%$ obtained through dilution of seawater from the Gulf of Guinea where the Kakum River empties into the ocean, while the other triplicate tanks contained freshwater of $0.04 \%$ o from the Kakum River. Each tank was $1 \mathrm{~m}$ high, had a diameter of $1.3 \mathrm{~m}$, contained $1 \mathrm{~m}^{3}$ of water, and stocked with 7 males and 21 females of the fish (i.e. a ratio of 1:3) since the species have low fecundity and a few males are enough to fertilize the eggs produced by many females as noted by Okyere (2012). The tanks were monitored daily for water temperature, dissolved oxygen (DO) and hydrogen ion concentration $(\mathrm{pH})$.

Since killifishes are substrate spawners (Joseph et al., 2018), acrylic mops commonly used by aquarists (Byrne, 1978) were provided as spawning substrates, each with one hundred strands (a strand was approximately $2 \mathrm{~mm}$ in diameter and $30 \mathrm{~cm}$ long). To investigate whether the killifish has preference for the colour of its spawning substrate, four conceivably contrasting colours of the mops (blue, green, white and black) were provided in each tank, where each colour was triplicated. The fish were fed with formulated feed commonly used in tilapia aquaculture as also used in a previous experiment by Okyere 
et. al. (2019), and the mops were monitored daily for eggs. Eggs laid on each mop were removed, counted and recorded, after which the freshly spawned ova were harvested into petri dish and immediately sent to the USAID Fisheries and Coastal Research Laboratory of the Department of Fisheries and Aquatic Sciences for further studies on embryonic development.

The embryos, immersed in water in the petri dish were mounted under a Motic digital compound microscope connected to a computer. With the aid of Motic software, the stages of embryonic development were monitored on computer screen using the $\times 10$ objective, and images of key developmental stages were captured. The duration for transition from formation of blastula, cleavage and epiboly to hatching as well as the circumference of the embryos at each of these stages were recorded using the utility tools of the Motic plus software.

Chi-squared test (Zar, 1999) was used to determine the statistical significance of differences between the number of eggs laid under freshwater and brackish water conditions as well as on the different colours of mops. The significance of the differences between the time taken to reach key embryonic stages and circumference of the embryos in the fresh and brackish water was ascertained using Student t-test (Zar, 1999).

\section{Ethical Statement}

Aplocheilichthys spilauchen is not listed as threatened species on the IUCN Red List, and the use the species for experiments do not require ethical clearance in Ghana.

\section{Results}

\section{Summary of physico-chemical conditions in the tanks}

Physico-chemical conditions were similar in both freshwater and brackish water tanks (Table 1), with a mean dissolved oxygen of $3.1 \mathrm{mg} / \mathrm{l}$, temperature of averagely $28^{\circ} \mathrm{C}$ and neutral (7.4 in freshwater) to near alkaline (7.9 in brackish water) $\mathrm{pH}$ recorded during the experiment.

\section{Size distribution of fish specimens}

A total of 168 A. spilauchen specimens were used for the study, the smallest being $4.1 \mathrm{~cm}$ TL and the largest measuring $6.1 \mathrm{~cm}$ long. The fish sample showed a normal distribution with individuals within the 5.0-5.1 cm class constituting the mode (Fig. 1). A Kolmogorov-Smirnov Normality Test (D) confirmed that the length distribution of the specimens was normal $(D=0.070 ; P>0.05)$.

Table 1: Physicochemical conditions in the experimental tanks (standard error in parenthesis) 


\begin{tabular}{|llll|}
\hline Parameter & \multicolumn{2}{l}{ Range } & Mean $\pm($ SE) \\
\cline { 2 - 3 } & Min & Max & \\
\hline Freshwater & & & \\
\hline DO $(\mathrm{mg} / \mathrm{L})$ & 2.9 & 3.4 & $3.1 \pm 0.2)$ \\
\hline Temperature $\left({ }^{\circ} \mathrm{C}\right)$ & 27.5 & 28.6 & $28.0( \pm 0.4)$ \\
\hline $\mathrm{pH}$ & 7.2 & 7.5 & $7.4( \pm 0.1)$ \\
\hline Brackish water & & & \\
\hline DO (mg/L) & 2.8 & 3.4 & $3.1( \pm 0.2)$ \\
\hline Temperature $\left({ }^{\circ} \mathrm{C}\right)$ & 27.6 & 28.8 & $28.2( \pm 0.3)$ \\
\hline $\mathrm{pH}$ & 7.5 & 8.3 & $7.9( \pm 0.2)$ \\
\hline
\end{tabular}

\section{Figure 1}

\section{Spawning potential and substrate colour preference}

A total of 30,263 eggs were collected over the period of study, of which 12,978 were spawned by the fish in the freshwater set-up, and 17,285 from specimens in the brackish water tanks (Table 2). Significantly higher number of eggs were laid in the brackish water than the freshwater $\left(\mathbb{Z}^{2}=1613.0, P<0.05\right)$. Of the four mop colours, black mops appeared as the most preferred spawning substrate, with the number of eggs laid on the black being about twice higher than the other colours in both waters $\left(\mathbb{Z}^{2}=1669.8, P<\right.$ 0.05 for freshwater; and $\square^{2}=2735.0, P<0.05$ for brackish water). The white mop recorded the lowest egg counts in both water systems, suggesting white as the least preferred spawning substrate by the fish. Generally, the observed substrate colour preference by the killifish in a decreasing order was black, green, blue and white.

\section{Embryonic developmental stages, sizes and duration in fresh-and -brackish water set-ups}

The embryonic developmental stages observed and monitored were the cleavage stage characterised by cell divisions $(2,4,816,32,64)$, blastulation stage observed from 128 cell divisions and beyond, gastrulation stage (occurring from $15 \%$ epiboly, 50\% epiboly, $75 \%$ epiboly and $100 \%$ epiboly), the early organogenesis characterised by appearance of eye buds, brain and the heart, pigmentation stage with appearance of dark pigments, late organogenesis and finally hatching. Key among these stages where clear images were captured are shown in Figure 2.

Table 2. Number of eggs collected from the freshwater and brackish water set-ups, and for the different colours of mops 


\begin{tabular}{|c|c|c|c|c|c|c|c|c|}
\hline \multirow{2}{*}{$\begin{array}{l}\text { Tank } \\
\text { Replicate }\end{array}$} & \multicolumn{5}{|c|}{ Mop colour and number of eggs collected } & \multirow{2}{*}{$\begin{array}{l}\text { Ratio } \\
\text { B: G: W: Bk }\end{array}$} & \multirow[t]{2}{*}{$\chi^{2}$} & \multirow[t]{2}{*}{$\mathrm{P}_{(0.05)}$} \\
\hline & $\begin{array}{l}\text { Blue } \\
\text { (B) }\end{array}$ & $\begin{array}{l}\text { Green } \\
(\mathrm{G})\end{array}$ & $\begin{array}{l}\text { White } \\
\text { (W) }\end{array}$ & $\begin{array}{l}\text { Black } \\
\text { (Bk) }\end{array}$ & Total & & & \\
\hline \multicolumn{9}{|c|}{ Freshwater (FW) } \\
\hline 1 & 1144 & 1100 & 1365 & 2384 & & & & \\
\hline 2 & 736 & 889 & 667 & 1779 & & & & \\
\hline 3 & 700 & 689 & 432 & 1093 & & & & \\
\hline Sub-Total & 2580 & 2678 & 2464 & 5256 & 12978 & $\begin{array}{l}\text { 1: 1.1: 1: } \\
2.1\end{array}$ & 1669.8 & $s$ \\
\hline \multicolumn{9}{|c|}{ Brackish water (BW) } \\
\hline 1 & 1359 & 1356 & 948 & 2483 & & & & \\
\hline 2 & 1064 & 990 & 1028 & 2260 & & & & \\
\hline 3 & 1024 & 1396 & 874 & 2503 & & & & \\
\hline Sub-Total & 3447 & 3742 & 2850 & 7246 & 17285 & $\begin{array}{l}\text { 1.2: 1.3: } 1: \\
2.5\end{array}$ & 2735.0 & $S$ \\
\hline \multicolumn{6}{|l|}{ Overall } & \multicolumn{3}{|l|}{$F W: B W$} \\
\hline \multicolumn{5}{|c|}{ Total FW \& BW } & 30263 & 1: 1.3 & $\begin{array}{l}1 \\
613.0\end{array}$ & $S$ \\
\hline \multicolumn{9}{|c|}{ Sindicates significant at the $5 \%$ significance level $(a=0.05)$} \\
\hline
\end{tabular}

\section{Figure 2}

As presented in Table 3, the cleavage stage was rapid, occurring within the first 30 minutes after fertilisation and completing in roughly 24 hours (in Day 1 of development). Organogenesis commenced in averagely the $25^{\text {th }}$ hour while pigmentation occurred between the $43^{\text {rd }}$ and $44^{\text {th }}$ hour (i.e. both commenced in Day 2), and both progressed through to 230 hours (between Day 9 and 10) when the embryos hatched. Development of embryos to reach most of the stages was comparatively faster in the freshwater than the brackish water, however, there was no statistical difference in the overall duration taken to hatch in the two waters. Similarly, results of the measurement of egg circumference showed that the freshwater eggs were comparatively bigger than the brackish water eggs at any development stage although the differences were not statistically significant after the early cleavage stages.

Table 3: Duration and circumference of $A$. spilauchen embryos in freshwater and brackish water tanks at the different stages of development; Mean \pm (Standard Error) 


\begin{tabular}{|c|c|c|c|c|c|c|}
\hline \multirow[t]{2}{*}{$\begin{array}{l}\text { EMBRYONIC } \\
\text { STAGES }\end{array}$} & \multicolumn{3}{|c|}{$\begin{array}{l}\text { CIRCUMFERENCE OF EMBRYO } \\
(\mu \mathrm{m})\end{array}$} & \multicolumn{3}{|c|}{ DURATION OF DEVELOPMENT } \\
\hline & Freshwater & $\begin{array}{l}\text { Brackish } \\
\text { water }\end{array}$ & $\begin{array}{l}\mathrm{P}- \\
\text { values }\end{array}$ & Freshwater & $\begin{array}{l}\text { Brackish } \\
\text { water }\end{array}$ & $\begin{array}{l}\mathrm{P} \text { - } \\
\text { values }\end{array}$ \\
\hline \multicolumn{7}{|l|}{ Cleavage } \\
\hline 2 Cells & $\begin{array}{l}249.1 \\
( \pm 18.4)\end{array}$ & $\begin{array}{l}236.0 \\
( \pm 12.5)\end{array}$ & $\begin{array}{l}0.01 \\
(S)\end{array}$ & $\underset{2 \mathrm{~min})}{27 \min ( \pm}$ & $\begin{array}{l}32 \min ( \pm 9 \\
\min )\end{array}$ & $\begin{array}{l}0.08 \\
\text { (NS) }\end{array}$ \\
\hline 4 Cells & $\begin{array}{l}249.6 \\
( \pm 19.7)\end{array}$ & $\begin{array}{l}235.2 \\
( \pm 9.32)\end{array}$ & $\begin{array}{l}0.01 \\
(S)\end{array}$ & $\begin{array}{l}1 \mathrm{~h}, 11 \min ( \pm \\
2 \mathrm{~min})\end{array}$ & $\begin{array}{l}1 \mathrm{~h}, 19 \min ( \pm \\
11 \mathrm{~min})\end{array}$ & $\begin{array}{l}0.01 \\
(S)\end{array}$ \\
\hline 8 Cells & $\begin{array}{l}250.3 \\
( \pm 17.9)\end{array}$ & $\begin{array}{l}238.2 \\
( \pm 11.3)\end{array}$ & $\begin{array}{l}0.01 \\
(S)\end{array}$ & $\begin{array}{l}1 \mathrm{~h}, 32 \mathrm{~min}( \pm \\
8 \mathrm{~min})\end{array}$ & $\begin{array}{l}2 \mathrm{~h}, 17 \mathrm{~min}( \pm \\
25 \mathrm{~min})\end{array}$ & $\begin{array}{l}0.00 \\
(S)\end{array}$ \\
\hline 16 Cells & $\begin{array}{l}248.7 \\
( \pm 19.3)\end{array}$ & $\begin{array}{l}237.1 \\
( \pm 11.2)\end{array}$ & $\begin{array}{l}0.03 \\
(S)\end{array}$ & $\begin{array}{l}2 \mathrm{~h}, 14 \min ( \pm \\
5 \mathrm{~min})\end{array}$ & $\begin{array}{l}2 \mathrm{~h}, 45 \min ( \pm \\
32 \mathrm{~min})\end{array}$ & $\begin{array}{l}0.00 \\
(S)\end{array}$ \\
\hline 32 Cells & $\begin{array}{l}248.7 \\
( \pm 18.7)\end{array}$ & $\begin{array}{l}236.4 \\
( \pm 12.2)\end{array}$ & $\begin{array}{l}0.02 \\
(S)\end{array}$ & $\begin{array}{l}3 \mathrm{~h}, 5 \mathrm{~min}( \pm \\
20 \mathrm{~min})\end{array}$ & $\begin{array}{l}3 \mathrm{~h}, 35 \mathrm{~min}( \pm \\
35 \mathrm{~min})\end{array}$ & $\begin{array}{l}0.00 \\
(S)\end{array}$ \\
\hline 64 - Beyond & $\begin{array}{l}245.2 \\
( \pm 20.7)\end{array}$ & $\begin{array}{l}239.2 \\
( \pm 15.0)\end{array}$ & $\begin{array}{l}0.30 \\
\text { (NS) }\end{array}$ & $\begin{array}{l}3 \mathrm{~h}, 20 \min ( \pm \\
17 \mathrm{~min})\end{array}$ & $\begin{array}{l}4 \mathrm{~h}, 13 \mathrm{~min}( \pm \\
35 \mathrm{~min})\end{array}$ & $\begin{array}{l}0.00 \\
(S)\end{array}$ \\
\hline 15\% Epiboly & $\begin{array}{l}244.6 \\
( \pm 17.6)\end{array}$ & $\begin{array}{l}237.5 \\
( \pm 10.3)\end{array}$ & $\begin{array}{l}0.13 \\
\text { (NS) }\end{array}$ & $\begin{array}{l}11 \mathrm{~h}, 23 \min ( \pm \\
19 \mathrm{~min})\end{array}$ & $\begin{array}{l}12 \mathrm{~h}, 38 \mathrm{~min} \\
( \pm 40 \mathrm{~min})\end{array}$ & $\begin{array}{l}0.00 \\
(S)\end{array}$ \\
\hline \multicolumn{7}{|l|}{ Gastrulation } \\
\hline 50\% Epiboly & $\begin{array}{l}244.2 \\
( \pm 16.6)\end{array}$ & $\begin{array}{l}238.6( \pm \\
9.4)\end{array}$ & $\begin{array}{l}0.20 \\
\text { (NS) }\end{array}$ & $\begin{array}{l}13 \mathrm{~h}, 55 \mathrm{~min}( \pm \\
30 \mathrm{~min})\end{array}$ & $\begin{array}{l}14 \mathrm{~h}, 17 \mathrm{~min} \\
( \pm 51 \mathrm{~min})\end{array}$ & $\begin{array}{l}0.05 \\
\text { (NS) }\end{array}$ \\
\hline 75\% Epiboly & $\begin{array}{l}246.0 \\
( \pm 18.3)\end{array}$ & $\begin{array}{l}237.4 \\
( \pm 12.6)\end{array}$ & $\begin{array}{l}0.09 \\
\text { (NS) }\end{array}$ & $\begin{array}{l}17 \mathrm{~h}, 1 \mathrm{~min}( \pm \\
56 \mathrm{~min})\end{array}$ & $\begin{array}{l}17 \mathrm{~h}, 23 \mathrm{~min} \\
( \pm 62 \mathrm{~min})\end{array}$ & $\begin{array}{l}0.19 \\
\text { (NS) }\end{array}$ \\
\hline 100\% Epiboly & $\begin{array}{l}245.6 \\
( \pm 15.9)\end{array}$ & $\begin{array}{l}236.1 \\
( \pm 11.4)\end{array}$ & $\begin{array}{l}0.04 \\
(S)\end{array}$ & $\begin{array}{l}21 \mathrm{~h}, 17 \mathrm{~min}( \pm \\
17 \mathrm{~min})\end{array}$ & $\begin{array}{l}22 \mathrm{~h}, 5 \min ( \pm \\
1 \mathrm{~h})\end{array}$ & $\begin{array}{l}0.00 \\
(S)\end{array}$ \\
\hline Organogenesis & $\begin{array}{l}239.8 \\
( \pm 14.5)\end{array}$ & $\begin{array}{l}237.5 \\
( \pm 12.8)\end{array}$ & $\begin{array}{l}0.18 \\
\text { (NS) }\end{array}$ & $\begin{array}{l}25 \mathrm{~h}, 22 \mathrm{mins} \\
( \pm 41 \mathrm{~min})\end{array}$ & $\begin{array}{l}25 \mathrm{~h}, 55 \mathrm{~min} \\
( \pm 58 \mathrm{~min})\end{array}$ & $\begin{array}{l}0.02 \\
(S)\end{array}$ \\
\hline Pigmentation & $\begin{array}{l}243.1 \\
( \pm 7.0)\end{array}$ & $\begin{array}{l}239.6 \\
( \pm 10.0)\end{array}$ & $\begin{array}{l}0.20 \\
\text { (NS) }\end{array}$ & $\begin{array}{l}43 \mathrm{~h}, 1 \mathrm{~min}( \pm \\
2 \mathrm{~h})\end{array}$ & $\begin{array}{l}44 \mathrm{~h}, 22 \mathrm{~min} \\
( \pm 2 \mathrm{~h})\end{array}$ & $\begin{array}{l}0.04 \\
(S)\end{array}$ \\
\hline Hatching & - & - & - & $\begin{array}{l}232 \mathrm{~h}, 3 \mathrm{~min}( \pm \\
12 \mathrm{~h})\end{array}$ & $\begin{array}{l}233 \mathrm{~h}, 30 \mathrm{~min} \\
( \pm 8 \mathrm{~h})\end{array}$ & $\begin{array}{l}0.56 \\
\text { (NS) }\end{array}$ \\
\hline
\end{tabular}

\section{Discussion}


Killifishes have evolved to occupy a wide range of habitats within freshwater, brackish water and saline ecosystems (Wildekamp, 1995). Even different species within a genus (e.g. Fundulus) are reported to show varied levels of salt tolerance and are adapted to surviving at different salinities (Whitehead, 2010). In Eurasia, the Mediterranean coast of Africa and North America, more species live in brackish water while in South America and sub-Saharan Africa, a majority are freshwater inhabitants (Ghedotti and Davis, 2013; Van der Zee et al., 2007; Wildekamp et al., 1986; Wildekamp and Van der Zee, 2003;). Of the few species in sub-Saharan Africa that inhabit brackish water environments, Aplocheilichthys spilauchen, Poropanchax scheeli, Pantanodon madagascariensis and P. stuhlmanniare the well-known members (Wildekamp et al., 1986) although these species are also tolerant of freshwater. The stronger association with brackish water possibly explains why $A$. spilauchen spawned significant number of eggs at the salinity of $5.01 \%$ o than the $0.04 \%$ during the present experiment. This spawning habit is inconsistent with observations on other killifishes such as the Iberian killifish Aphanius iberus- where Oltra and Todolí (2000) found no significant differences between the number of spawns at different salinities.

A considerable number of studies have been carried out on colour preference of fin-and-shellfishes widely covering effects of colour preference on fish learning (Roy et al., 2019), fish feeding (Cole and Endler, 2015), prawn shelter (Kawamura et al., 2017), shrimp growth (Freire et al., 2012), fish mating behaviour (Seehausen et al., 1998), among others. In the bluefin killifish Lucania goodei, pecking behaviour has been found to be associated with blue and red colours (Johnson et al., 2013), but beyond this report, studies on colour preference of killifishes for other biological and behavioural purposes remain dearth despite the growing interests in varied utilisation of these fishes. Traditionally, killifish breeders have chosen spawning mops that are darker to enable easy spotting of the eggs laid since the whitish transparent eggs are easily visible on a dark background. The selection of spawning substrate by breeders has not been based on empirical studies on substrate colour preference by the fish. In fact, some killifish breeding sources even suggest that the fish will not care about the spawning substrate colour (Aquatic Community, 2004). Results of the current study, however, shows that the banded lampeye killifish has preference for the colour of its spawning substrate, with the most preferred colour being black, followed by green and blue, and white being the least preferred. Although the black mop preference observed in this study may appear to corroborate the practice of using dark mops by breeders, it possible that different species may have preference for different spawning substrate colours and spawning could be optimised if the preferences are indentified.

In the field of killifish embryology, the early work of Wourms (1972) on Austrofundulus myersias well as recent works of Mourabit et al. (2011) together with Genade (2016) on Kryptolebias marmoratus, Podrabsky et al. (2017) on Austrofundulus limnaeus and Masoudi et al. (2018) on Aphanius sophiae, among others, have well documented the developmental stages from cleavage to hatching including pictorial appearance of the stages. In the present study, the development of $A$. spilauchen embryos followed same stages as reported for the other killifishes. No differences were observed between the physical appearance of the embryos in the freshwater and brackish water tanks. Although some minor disparities were observed for the duration of certain stages (faster in the freshwater than brackish water) and embryo size (freshwater eggs were bigger than the brackish water), these differences were overall not 
significant and had no effects on the overall duration of 230 hours (i.e. 9 to 10 days) taken to hatch. Osmotic effects could likely account for these imperceptible differences as freshwater eggs are susceptible to the influx of water while eggs in saline waters may tend to lose water and shrink in size due to the differences in osmotic gradient (Holliday,1969).

In conclusion, this experiment has demonstrated that $A$. spilauchen can be propagated through captive breeding. Using brackish water of $5 \%$ o salinity yielded more seed than freshwater, and providing black mops as spawning susbstrate also yielded significantly higher spawns than green, blue and white mops. Inferably, for optimal spawning of the lampeye, breeding should be carried out under brackish water condition using black mops. The outcome of this study offers a significant step for the mosquito biocontrol programme since the predator, $A$. spilauchen, can be optimally propagated and disseminated in a few weeks. It is important to emphasise that for future breeding programs and introduction of $A$. spilauchen, local populations should be used since reports indicate there are large genetic distances between different populations. Aside from the biocontrol, the work also opens a new discussion on the prospects of breeding the lampeye as baitfish for the Tuna Fishing Industry in Ghana given that the declined small pelagic stocks in country has rendered anchovies (Engraulis encrasicolus - the traditional baitfish for the industry) unavailable and alternatives are currently being sought. Finally, our research complements the works of others such as Bragança and Costa (2019) in promoting research on African lampeyes.

\section{Declarations}

\section{Acknowledgements}

The authors are grateful to the Directorate of Research, Innovation and Consultancy (DRIC), University of Cape Coast (UCC), Ghana for providing financial support for this research, and the Department of Fisheries and Aquatic Sciences (DFAS)-UCC for providing laboratory space and facilities for the research. We are particularly thankful to Prof. Justice Kwabena Sarfo, the Dean of School of Biological Sciences, UCC for facilitating the National Service placement of Juliet Afrah Obeng at the School to work on this project.

\section{Declarations of interest: none}

Contribution of authors: Isaac Okyere was responsible for overall coordination of the project including data collection and analysis, and drafting of part of the manuscript. Juliet Afrah Obeng and Samuel Ayitey carried out the in the experimentation, including data collection and analyses, while Jouke Rients Van der Zee and Herman Meeus designed the experiment, provided the spawning mops, identified embryonic stages, and carried out final revision of the manuscript. All authors have approved the final article.

Funding: This work was supported by the Directorate of Research, Innovation and Consultancy (DRIC) of the University of Cape Coast (UCC), Ghana [UCC-DRIC-RSG-INDIV.LED-2018]. 


\section{References}

Aquatic Community (2004). Killiefish mops. Available at http://www.aquaticcommunity.com/killi/mops.php. (last accessed 2 November 2020) .

Bragança, P. H., \& Costa, W. J. (2019). Multigene fossil-calibrated analysis of the African lampeyes (Cyprinodontoidei: Procatopodidae) reveals an early Oligocene origin and Neogene diversification driven by palaeogeographic and palaeoclimatic events. Organisms Diversity \& Evolution, 19(2), 303-320. https://doi.org/10.1007/s13127-019-00396-1

Byrne, D. M. (1978). Life history of the spotfin killifish, fundulus luciae (pisces: cyprinodontidae), in Fox Creek Marsh, Virginia. Estuaries, 1(4), 211-227. https://doi.org/10.2307/1351523

Chesser, B. M., Green, C. C., \& Allen, P. J. (2019). Egg Production of Gulf Killifish Is Dependent on Broodstock Rearing Density but Not Spawning Substrate Surface Area. North American Journal of Aquaculture, 81(3), 201-210. https://doi.org/10.1002/naaq.10087

Cole, G. L., \& Endler, J. A. (2015). Artificial selection for food colour preferences. Proceedings of the Royal Society B: Biological Sciences, 282(1804), 20143108. https://doi.org/10.1098/rspb.2014.3108

Dabiré, K. R., Diabaté, A., Djogbenou, L., Ouari, A., N'Guessan, R., Ouédraogo, J. B, Hougard, J. M., Chandre, F. \& Baldet, T. (2008). Dynamics of multiple insecticide resistance in the malaria vector Anopheles gambiae in a rice growing area in South-Western Burkina Faso. Malaria Journal, 7(1), 188. https://doi.org/10.1186/1475-2875-7-188

Freire, F. A. M., Luchiari, A. C., \& Marques, A. O. (2012). Effects of substrate colour preference on growth of the shrimp Litopenaeus vannamei (Boone, 1931)(Decapoda, Penaeoidea). Crustaceana, 85(7), 789-800. https://doi.org/10.1163/156854012X650232

Genade, T. (2016). The Use of" Kryptolebias marmoratus" Eggs as an Educational Tool for Embryology Education. Bioscene: Journal of College Biology Teaching, 42(2), 26-31.

Ghedotti, M.J. \& Davis, M.P. (2013). Phylogeny, Classification, and Evolution of Salinity Tolerance of the North American Topminnows and Killifishes, Family Fundulidae (Teleostei: Cyprinodontiformes). FIELDIANA: LIFE AND EARTH SCIENCES, NO. 7, February 13, 2013, pp. 1-65.

Ghosh, A., Bhattacharjee, I., Ganguly, M., Mondal, S., \& Chandra, G. (2004). Efficacy of some common aquarium fishes as biocontrol agent of preadult mosquitoes. Buletin Penelitian Kesehatan, 32(4 Des) $(144-149)$.

Holliday, F. G. T. (1969). The Effects of Salinity on the Eggs and Larvae of Teleosts. In Fish physiology, Chapter 4 (Vol. 1, pp. 293-311). Academic press. https://doi.org/10.1016/S1546-5098(08)60085-0 
Johnson, A. M., Stanis, S., \& Fuller, R. C. (2013). Diurnal lighting patterns and habitat alter opsin expression and colour preferences in a killifish. Proceedings of the Royal Society B: Biological Sciences, 280(1763), 20130796. https://doi.org/10.1098/rspb.2013.0796

Joseph, L. M., Ohs, C. L., DiMaggio, M. A., \& Broach, J. S. (2017). Effects of brood density and spawning substrate type and orientation on the reproductive output of Seminole Killifish in tanks. North American Journal of Aquaculture, 79(4), 267-274. https://doi.org/10.1080/15222055.2017.1330787

Kawamura, G., Bagarinao, T., Yong, A. S. K., Fen, T. C., \& Lim, L. S. (2017). Shelter colour preference of the postlarvae of the giant freshwater prawn Macrobrachium rosenbergii. Fisheries science, 83(2), 259-264. https://doi.org/10.1007/s12562-017-1062-8

Lanés, L. E. K., Keppeler, F. W., \& Maltchik, L. (2012). Abundance, sex-ratio, length-weight relation, and condition factor of non-annual killifish Atlantirivulus riograndensis (Actinopterygii: Cyprinodontiformes: Rivulidae) in Lagoa do Peixe national park, a ramsar site of southern Brazil. Acta Ichthyologica et Piscatoria, 42(3). 247-252. https://doi.org/10.3750/AIP2011.42.3.09

Leyse, K. E., Lawler, S. P., \& Strange, T. (2004). Effects of an alien fish, Gambusia affinis, on an endemic California fairy shrimp, Linderiella occidentalis: implications for conservation of diversity in fishless waters. Biological Conservation, 118(1), 57-65. https://doi.org/10.1016/j.biocon.2003.07.008

Masoudi, M., Esmaeili, H. R., \& Ebrahimi, M. (2018). Embryology and early ontogeny of an endemic toothcarp fish, Aphanius sophiae (Heckel, 1847). Journal of Applied Ichthyology, 34(3), 622-632. https://doi.org/10.1111/jai.13630

Matias, J. R., \& Adrias, A. Q. (2010). The use of annual killifish in the biocontrol of the aquatic stages of mosquitoes in temporary bodies of fresh water; a potential new tool in vector control. Parasites \& vectors, 3(1), 46. doi: https://doi.org/10.1186/1756-3305-3-46

Mourabit, S., Edenbrow, M., Croft, D. P., \& Kudoh, T. (2011). Embryonic development of the self-fertilizing mangrove killifish Kryptolebias marmoratus. Developmental Dynamics, 240(7), 1694-1704. https://doi.org/10.1002/dvdy.22746

Munhenga, G., Masendu, H. T., Brooke, B. D., Hunt, R. H., \& Koekemoer, L. K. (2008). Pyrethroid resistance in the major malaria vector Anopheles arabiensis from Gwave, a malaria-endemic area in Zimbabwe. Malaria journal, 7(1), 247. https://doi.org/10.1186/1475-2875-7-247

Okyere, I. (2012). Some ambient environmental conditions, food and reproductive habits of the banded lampeye killifish Aplocheilichthys spilauchen in the Kakum estuary wetland, Ghana. Environmental biology of fishes, 94(4), 639-647. https://doi.org/10.1007/s10641-011-9970-4

Okyere, I., Kudom, A. A. \& Sakyi-Djan, P. (2019). Larval prey selectivity of the lampeye killifish Aplocheilichthys spilauchen and its potential for mosquito biocontrol. Biological Control 131, 69-73. 
Oltra, R., \& Todolí, R. (2000). Reproduction of the endangered killifish Aphanius iberus at different salinities. Environmental Biology of Fishes, 57(1), 113-115.

Podrabsky, J. E., Riggs, C. L., Romney, A. L., Woll, S. C., Wagner, J. T., Culpepper, K. M., \& Cleaver, T. G. (2017). Embryonic development of the annual killifish Austrofundulus limnaeus: An emerging model for ecological and evolutionary developmental biology research and instruction. Developmental Dynamics, 246(11), 779-801. https://doi.org/10.1002/dvdy.24513

Roy, T., Suriyampola, P. S., Flores, J., López, M., Hickey, C., Bhat, A., \& Martins, E. P. (2019). Color preferences affect learning in zebrafish, Danio rerio. Scientific reports, 9. https://doi.org/10.1038/s41598019-51145-5

Seehausen, O., \& van Alphen, J. J. (1998). The effect of male coloration on female mate choice in closely related Lake Victoria cichlids (Haplochromis nyererei complex). Behavioral Ecology and Sociobiology, 42(1), 1-8. https://doi.org/10.1007/s002650050405

Van der Zee, J. R., Woeltjes, T. \& Wildekamp, R.H. (2007). Poeciliidae. In: Stiassny, M.L.J., Teugels, G.G. \& Hopkins, C.D. (Eds.), The Fresh and Brackish Water Fishes of Lower Guinea, West-Central Africa. Vol. II. IRD Editions, Paris, pp. 48-79.

Whitehead, A. (2010). The evolutionary radiation of diverse osmotolerant physiologies in killifish (Fundulus sp.). Evolution: International Journal of Organic Evolution, 64(7), 2070-2085. https://doi.org/10.1111/j.1558-5646.2010.00957.x

Wildekamp R. H. (1995). A world of Killies: Atlas of the oviparous cyprinodontiform fishes of the world. Volume II: the genera Aplocheilichthys, Aplocheilus, Austrofundulus, Campellolebias, Crenichthys, Cualac, Cubanichthys. Cynolebias, Cynopoecilus, and Cyprinodon. American Killifish Association, Inc.

Wildekamp, R., Romand, R \& Scheel, J.J. Cyprinodontidae. In: Daget, J., Gosse, J-P. \& Thys van den Audenaerde D.F.E. (1986). Checklist of the Freshwater Fishes of Africa Vol. II.

Wildekamp, R. H. \& Van der Zee, J. R. (2003) Cyprinodontiformes. In: Paugy, D., Lévêque, C. \& Teugels, G. G. (Eds), The Fresh and Brackish Water Fishes of West Africa. Volume II. IRD Éditions, Paris, pp. 298-442.

Wourms, J. P. (1972). Developmental biology of annual fishes. I. Stages in the normal development of Austrofundulus myersi Dahl. Journal of Experimental Zoology, 182(2), 143-167. https://doi.org/10.1002/jez.1401820202

Zar J. H. (1999). Biostatistical analysis. Prentice Hall, Upper Saddle River

\section{Figures}




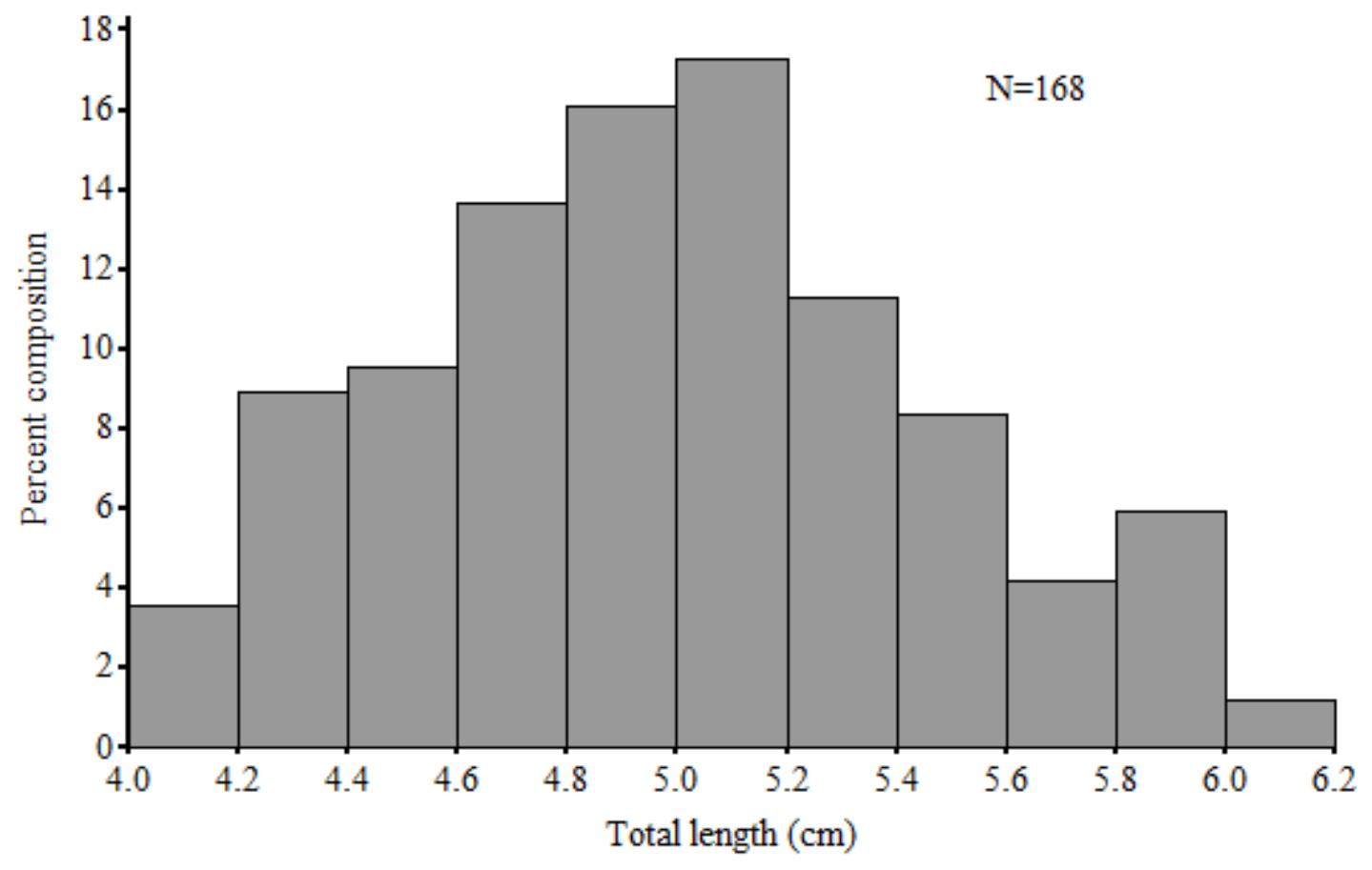

Figure 1

Length-frequency distribution of Aplocheilichthys spilauchen used for the experiment
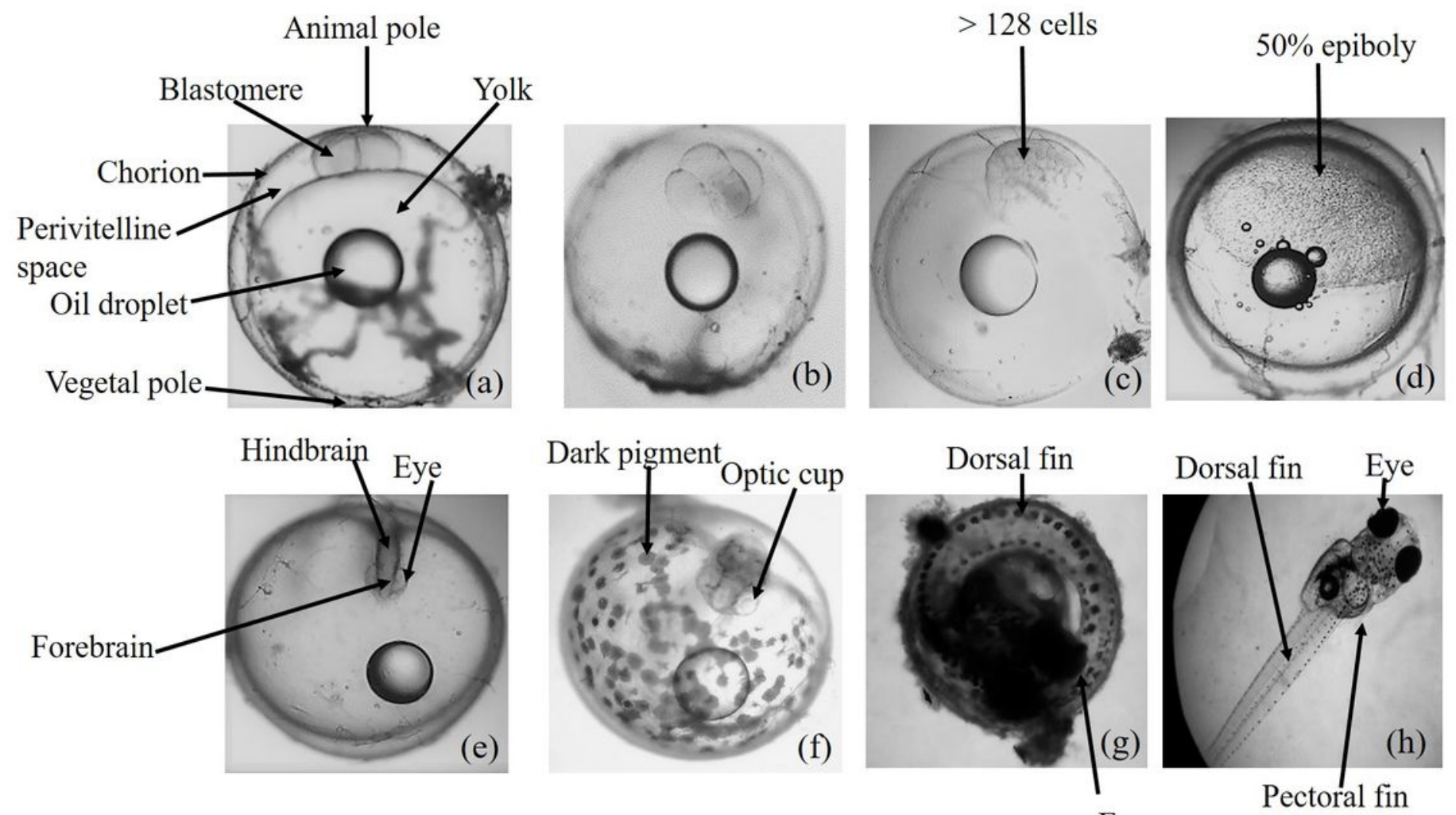

Eye 
Stages of development of Aplocheilichthys spilauchen embryo showing (a) cleavage (2-cell stage), (b) cleavage (4-cell stage), (c) blastulation stage, (d) gastrulation stage, (e) early organogenesis, ( $f$ ) pigmentation, $(\mathrm{g})$ late organogenesis, and $(\mathrm{h})$ hatchling (fry) 